\title{
Developing a Financial Literacy Storybook for Early Childhood in an Augmented Reality Context
}

\author{
Ratna Candra Sari \\ Department of Accounting Education, Faculty of Economics, Universitas Negeri Yogyakarta, Indonesia \\ ORCID: 0000-0002-3544-4168 \\ Mimin Nur Aisyah \\ Department of Accounting, Faculty of Economics, Universitas Negeri Yogyakarta, Indonesia \\ ORCID: 0000-0001-7215-5798
}

Sariyatul llyana

Department of Accounting, Faculty of Economics and Business, Universitas Gadjah Mada, Indonesia ORCID: 0000-0001-5487-860X

Hardika Dwi Hermawan

Informatics Engineering Education, Faculty of Teacher Training and Education, Universitas Muhammadiyah

Surakarta, Indonesia

ORCID: 0000-0003-2181-4989

Received: 4 Oct 2021

Accepted: 22 Jan 2022

\begin{abstract}
This study aims to develop and test the effectiveness of a financial literacy storybook based on augmented reality $(A R)$ as an executive function-building intervention for early-age children. Executive functions are the cognitive abilities underlying such tasks as focusing on long-term goals, delaying gratification and impulse self-control. The method is research and development using the ADDIE (analysis, design, development, implementation, and evaluation) model. This learning media produced a positive response among the users. Children perceive the story's attractiveness was good, while the 3D images and activity in the storybook were very good. This study also measures the effectiveness of a storybook based on AR in improving the understanding of financial literacy using a pre and post-test design. The results show that knowledge of honesty, discipline and money management increased significantly. In addition, there is a marginally significant increase in the aspects of delay gratification, saving goals and responsibility.
\end{abstract}

Keywords: executive functions, storybook, early childhood, augmented reality, financial literacy

\section{INTRODUCTION}

Indonesia has a low level of financial literacy at 38.03\% (OJK, 2019). However, educational material for developing financial literacy is still scarce, especially for those in early childhood. This is unfortunate, because executive functions as a strategy to introduce literacy into early childhood, grow rapidly in children aged 3 to 5 years (Harvey \& Miller 2017; McDermott et al., 2014; Moffitt et al., 2011; Purpura et al., 2017). Executive functions are the cognitive abilities underlying such tasks as focusing on long-term goals, delaying gratification, perseverance or 'grit' and include impulse self-control (Drever et al., 2015). The need to delay gratification and control one's impulses has become the most ubiquitous priority in children's education, 
because success in many life tasks, including financial success, depends on children's abilities to control themselves (Beisly et al., 2019; McClelland et al., 2013; Moffitt et al., 2011).

In today's digital world, many children are born into cultures where technology is naturally part of the environment. However, educational approaches are often detached from the learner's real-life context. Therefore, there is a need to incorporate technological advances in a critical and democratic manner (Hayashi, 1990). Designing instructional media is noteworthy if persuasive technology is incorporated into the design strategy, so that it is capable of changing a person's behavior (Consolvo et al., 2009; Devincenzi et al., 2017). This study aims to provide knowledge that supports the development of executive functions through creating financial literacy learning media based on augmented reality (AR) technology.

AR technology gives students a deep learning experience through two basic features of virtual technology: augmentation and interaction (Javornik, 2016). AR integrates virtual reality with the physical world, which helps children to mingle while learning, and interact with virtual objects in the real world. Augmented reality is a technology that provides the experience of interacting with the real world (Garzón et al., 2019). AR technology is able to provide a learning experience without having to actually leave home, so it is relevant to respond to situations due to the COVID-19 pandemic. This excellence in the field of education has made AR one of the main technologies to have emerged in education over the past five years (Chen et al., 2016; Martin et al., 2011). The innovation in augmented reality storybooks for educational purposes has become an innovation that shows positive values for students (Chen et al., 2016). It is expected that the design of financial literacy learning material, based on AR technology, can improve financial literacy in early childhood. Our research objectives can be listed as follows:

1. To develop a financial literacy storybook based on augmented reality as an executive function-building intervention for early-age children.

2. To test the effectiveness of a financial literacy storybook based on augmented reality.

\section{LITERATURE REVIEW}

\section{Theory of Interactive Media Effects (TIME)}

The theory of interactive media effect (TIME) is a theoretical framework to explain how interface features affect user psychology (Sundar et al., 2015). AR has two main characteristics: interactivity and augmentation (i.e., combining virtual objects with the physical environment) (Javornik, 2016). The interactive characteristic of computer-based media is one of the most important features (Fortin \& Dholakia, 2005) covering various interaction methods such as clicking, scrolling, dragging, and hovering over something. The use of AR can increase student interactivity, thereby increasing their intrinsic motivation. Increased motivation has a positive impact on user engagement with technology content which in turn has an impact on their cognition, attitudes and behavior (Sundar et al., 2012).

\section{Financial Literacy Strategy for Early Childhood}

Financial literacy learning strategies must be adjusted according to the age level of the students (Drever et al., 2015). At adulthood (13 to 21 years), the strategy used is financial skills' building through experiencebased, practical, education programmes, while for children aged 6 to 12 years old, financial socialisation strategies are used through parental and other adult guidance for basic financial learning skills and healthy financial attitudes. For children of pre-elementary school age ( 3 to 5 years old) an executive function development scheme is used. Executive functioning is the cognitive ability to focus on long-term goals. Cognitive abilities such as impulse control (Meier \& Sprenger, 2012) and long-term orientation abilities such as delaying gratification skills (Lynch et al., 2010) are needed to achieve one's financial goals (Drever et al., 2015). Delaying gratification refers to a person's ability to delay a present pleasure and focus on achieving their long-term goals. 


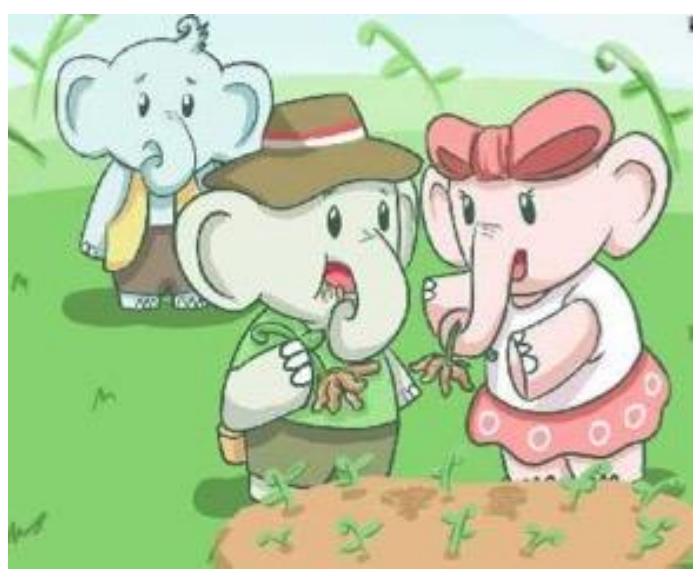

Figure 1. Executive function intervention through a storybook

Executive functioning has three subcomponents: inhibition, working memory and cognitive flexibility (Miyake et al., 2000). Inhibition is the ability to focus on a task in the face of internal and external distractions. This capability is very necessary to achieve financial well-being. Inhibition makes one stick to a shopping list and not be tempted by all the offers and items on sale that are not on the shopping list. The stronger the inhibition, the greater our ability to manage emotions (Diamond 2013) and money (Drever et al., 2015). Cognitive flexibility is the ability to produce alternative approaches to solving problems, including financial problems (Diamond, 2013). Working memory is the brain's ability to store and process multiple pieces of information at once. The three subcomponents of executive functioning are frequently used in tasks related to money management (Holden et al., 2009; Whitebread \& Bingham, 2013). For example, inhibitory control and working memory increase the ability not to be tempted by momentary pleasures (Diamond, 2013) and support the indispensable ability to focus on long-term goals, such as saving to buy a bicycle or a bag (Holden et al., 2009; Whitebread \& Bingham, 2013), whereas cognitive flexibility allows us to think of new ways to achieve what we want (Holden et al., 2009; Whitebread \& Bingham, 2013).

Executive functioning is related to financial well-being because it increases children's ability to delay their gratification in order to focus on their saving goals or the creativity to start their own business (Holden et al., 2009; Zimmerman et al., 2011). Financial education interventions for children include executive function interventions and basic financial skills such as identifying coins (Drever et al., 2015). Holden et al. (2009) created an intervention programme to improve the executive functions and basic financial skills, for example by teaching children strategies to focus on their saving goals when they are faced with immediate temptations. Examples of the strategies used include asking children to visualise their saving goals (for example, a bicycle, or a bag) when they are tempted to buy candy or an ice cream.

This study developed a financial literacy storybook for children which contained executive function interventions and the basic concepts of finance. For example, in this book, Ello, who is a character in the storybook, is unable to resist the temptation to eat peanuts every time his mother gives them to him, while his siblings Elli and Ella always set aside their nuts and plant them. After several months, Ello is sad to see Elli and Ella have a lot of peanuts which they grew, while Ello has none because he always ate his peanuts and did not save any to plant (Figure 1).

\section{The Effectiveness of AR-based Learning Media for Early Childhood}

Previous research examined the effectiveness of AR for early childhood education in various fields. For example, Rohaya et al. (2012) found that AR storybooks increase students' motivation to learn numbers and read folk stories. Cascales et al. (2013) argue that the use of AR promotes the active behaviour and learning achievement of students. It also improves the communication skills and interaction between students and their teachers, as well as providing a very positive experience for them. Safar et al. (2016) found a very strong correlation between children's interaction in AR-based English alphabet lessons and their scores on the English alphabet test. Rasalingam (2014) found that AR technology is effective in increasing motivation and 
engagement in learning in preschool children. The use of AR also improves children's learning outcomes during drama play (Han et al., 2015) and art activities (Huang et al., 2016).

Meanwhile, in the area of financial literacy education, the use of AR is still limited. Sari et al. (2022) found empirical evidence that students who received AR-based Islamic financial socialization has higher Islamic finance knowledge than the control group. Given the scarcity of research on the effectiveness of AR in relation to financial education for preschool students and the low level of financial literacy in Indonesia, this study fills a gap to develop and test the effectiveness of a financial literacy storybook in the context of AR. AR can be used and applied to instructional media as an innovation, so that learning becomes more attractive and interactive, especially for children (Bower et al., 2014; Gun \& Atasoy, 2017; Karlsson et al., 2017). The coexistence of virtual objects and the real environment allows students to experience phenomena that cannot occur in the real world (Klopfer \& Squire, 2008) and develop important practices and literacy that cannot be developed with other technologies (Squire \& Jan, 2007; Squire \& Klopfer, 2007). AR-based media interactivity has a positive impact on students' cognition, attitudes and behaviour (Sundar et al., 2012).

Employing modern educational technology is expected to improve teaching methods. Augmented reality technology may encourage children to develop their mental and cognitive skills to a greater extent than if they are only taught by traditional methods. To optimise the benefits of AR-based educational tools, Bistaman et al. (2018) suggested the use of collaborative learning when designing and engaging in an AR learning environment. The motivation and collaboration will be enhanced by the interaction of the teachers and children with an AR system. Therefore, we expect that the AR-based financial literacy storybook with collaborative learning should enable them to develop their cognitive skills.

\section{RESEARCH METHODOLOGY}

A research and development model was used in the development of AR-based financial literacy learning media to instill financial literacy in children from an early age. According to Dick et al. (2014), there are five stages for creating a research and development model: analysis, designing, development, implementation, and evaluation (ADDIE). Figure $\mathbf{2}$ presents the development life cycle of financial literacy material for early childhood in an augmented reality context. Moreover, in this research, the financial literacy storybook app is called the Ello Story.

In the process of developing the media, the researcher first conducted analysis using data obtained from observations in the classroom and interviews with teachers. The results of the analysis became the basis for designing the financial literacy learning media, so it can be used effectively by being based on what is needed. The next stage was the development stage, in which the researcher arranged the storyboard and developed the learning media based on it. After the product's development, the researcher implemented the financial literacy learning media based on augmented reality. This stage was a trial of the product and an assessment of its associated media.

We invited experts to validate the learning media. Three material experts assessed the content and two media experts assessed the quality of AR technology-based learning media. The material experts were a lecturer in early childhood education, a lecturer in economics, and a kindergarten teacher. The media experts were lecturers of the Faculty of Informatics and lecturers of the Faculty of Education. These lecturers were selected according to their respective fields of expertise in the development of technology and learning technology.

The last stage in the media's development was evaluation. Before the evaluation phase, the researchers asked the parents and teachers for permission to conduct this research on the children. The AR storybooks were implemented in kindergartens in the Yogyakarta region of Indonesia with 20 students, three times a week for three weeks. The average age of the participants was 5.2 years and the majority had parents with a bachelor's degree. Detailed participant demographic information is in Appendix A. The implementation of this learning media used collaborative learning. Collaborative learning is a model where knowledge can be created within a population whose members actively interact through sharing experiences and asymmetric 


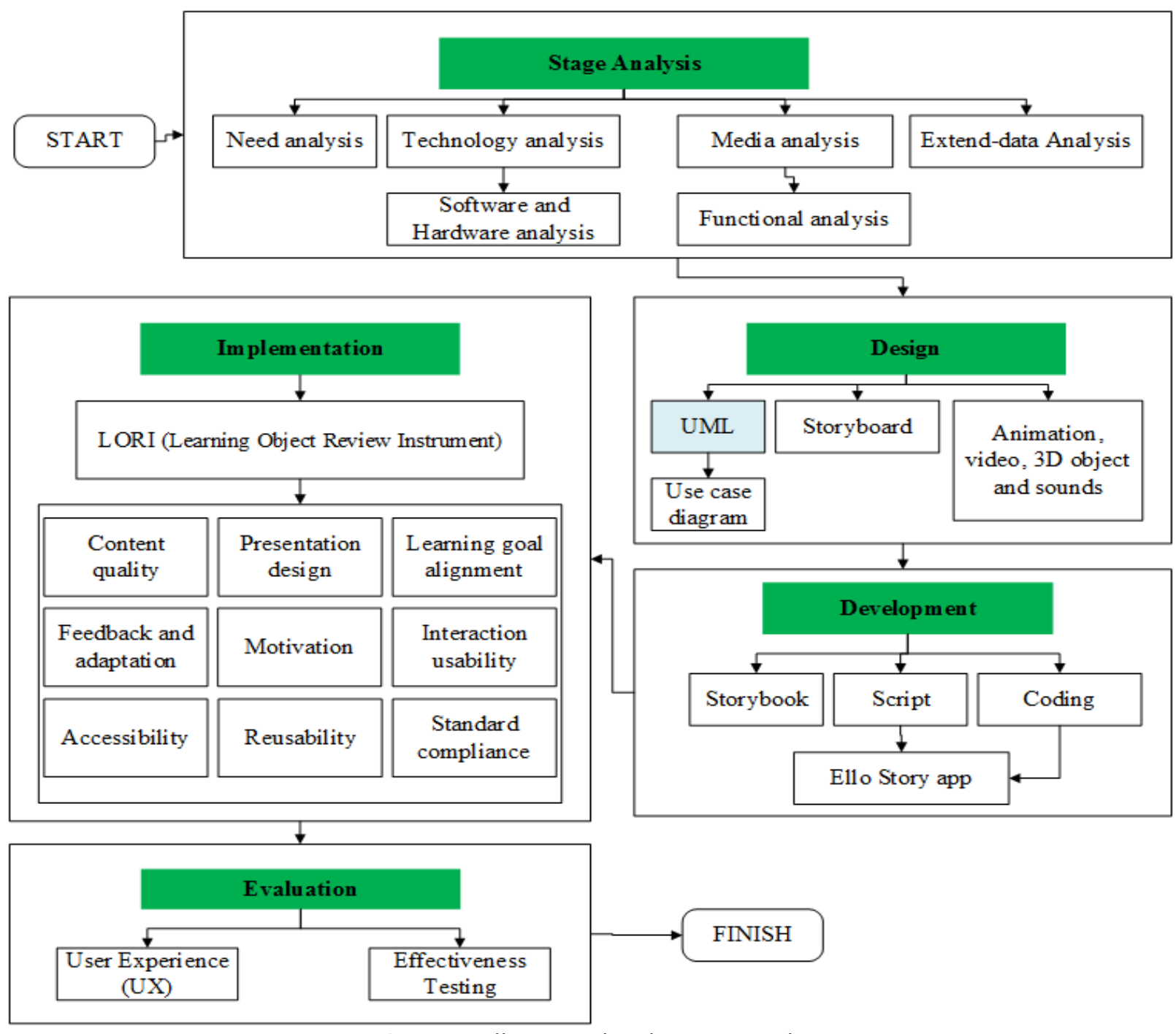

Figure 2. Ello Story development cycle

roles (Mitnik et al., 2009). In this case the teacher read stories to the children in the class, demonstrated the use of the technology, discussed the values implied in the stories and listened to the opinions of the children about their learning experience.

The evaluation phase consisted of two parts: the users' experience and effectiveness testing. At the user experience stage, the students responded to the storybook in relation to its attractiveness, content, figures, 3D images, and activities. An example of question to determine the attractiveness is: 'Do you think this book is interesting?' They responded by selecting a smile emoticon image for strongly like and a sullen emoticon for strongly dislike. Effectiveness testing used an experimental method, with a pre- and post-test design. Table 1 shows the indicators and questions provided by the teacher to the students. This experimental method was to evaluate the improvement in the children's understanding of financial literacy.

The tests were used to examine the effectiveness of financial literacy education using an AR-based storybook. Tests were given before and after the learning. The marshmallow test was measured by the length of time the child was able to resist the temptation to eat the marshmallow. Other items were assessed by the teacher based on the results of interviews with students with the teacher assessing students' answers using a scale score of 1 (do not understand) to 5 (understand). To test the reliability of the items, Cronbach's alpha was computed. The alpha for the items was .71 indicating the items is acceptable (George \& Mallery, 2003). 
Table 1. Indicator and test of executive functioning

\begin{tabular}{|c|c|c|c|}
\hline $\begin{array}{l}\text { Subcomponent of } \\
\text { executive functioning }\end{array}$ & Definition & Indicator & Test \\
\hline \multirow[t]{2}{*}{ Inhibition } & \multirow[t]{2}{*}{$\begin{array}{l}\text { The ability to focus on a task in } \\
\text { the face of internal and external } \\
\text { distractions }\end{array}$} & $\begin{array}{l}\text { Delay } \\
\text { gratification }\end{array}$ & $\begin{array}{l}\text { Marshmallow test (Put the marshmallow in } \\
\text { front of the student and tell the student that } \\
\text { he/she will get another marshmallow in } 15 \\
\text { minutes time if he/she does not eat the first } \\
\text { marshmallow) }\end{array}$ \\
\hline & & Saving's goal & $\begin{array}{l}\text { Do you have any savings? } \\
\text { What are you saving for? } \\
\text { Is saving good? } \\
\text { What are the benefits of saving money? } \\
\text { What can you achieve by saving money? }\end{array}$ \\
\hline \multirow[t]{3}{*}{ Working memory } & \multirow{3}{*}{$\begin{array}{l}\text { The brain's ability to store and } \\
\text { process multiple items of } \\
\text { information at once }\end{array}$} & Honesty & $\begin{array}{l}\text { What does it mean to be honest? } \\
\text { What is the impact when we are honest? }\end{array}$ \\
\hline & & Responsibility & $\begin{array}{l}\text { What is a responsible attitude? } \\
\text { What is the impact of being responsible? }\end{array}$ \\
\hline & & Discipline & $\begin{array}{l}\text { What is discipline? } \\
\text { What is the impact of discipline? }\end{array}$ \\
\hline Cognitive flexibility & $\begin{array}{l}\text { The ability to produce alternative } \\
\text { approaches to solving problems, } \\
\text { including financial problems }\end{array}$ & $\begin{array}{l}\text { Money } \\
\text { management }\end{array}$ & $\begin{array}{l}\text { How do you use money? } \\
\text { What money do you have for? }\end{array}$ \\
\hline
\end{tabular}

\section{FINDINGS}

The purpose of this research was to develop a financial literacy storybook for early childhood in an augmented reality context. The development process employed the ADDIE process (analysis, design, development, implementation, and evaluation).

\section{Analysis Phase}

The analysis phase was the basic and fundamental stage, so the material was developed according to the need for its development, and for the technology and media to be used. The analysis phase in this research consisted of several stages, a needs assessment and an analysis of the technology, media and the extenddata.

\section{Needs assessment}

A needs assessment is an analysis undertaken to identify the difference between the actual situation and the circumstances expected by the researchers. In Indonesia, students have financial literacy scores significantly below the OECD average score (OECD, 2018). Students have challenges in answering some basic financial knowledge. Other students also said that they are not interested in studying financial literacy due to the lack of learning media that is interesting and appropriate for their age level.

Based on observations and interviews with the teachers, parents and children, there is still a lack of financial literacy learning materials for children based on AR technology. Meanwhile, AR makes learning become more attractive and interactive, especially for children Therefore, developing learning media that is in accordance with young learners' preferences is significant to help childhood improve students' understanding of financial literacy.

\section{Technology analysis}

Technology analysis aims to identify existing technological capabilities. Currently, smartphone technology is affordable and most teachers and parents have android-based smartphone devices. This android-based smartphone technology is used to access the augmented reality's financial literacy storybook. 


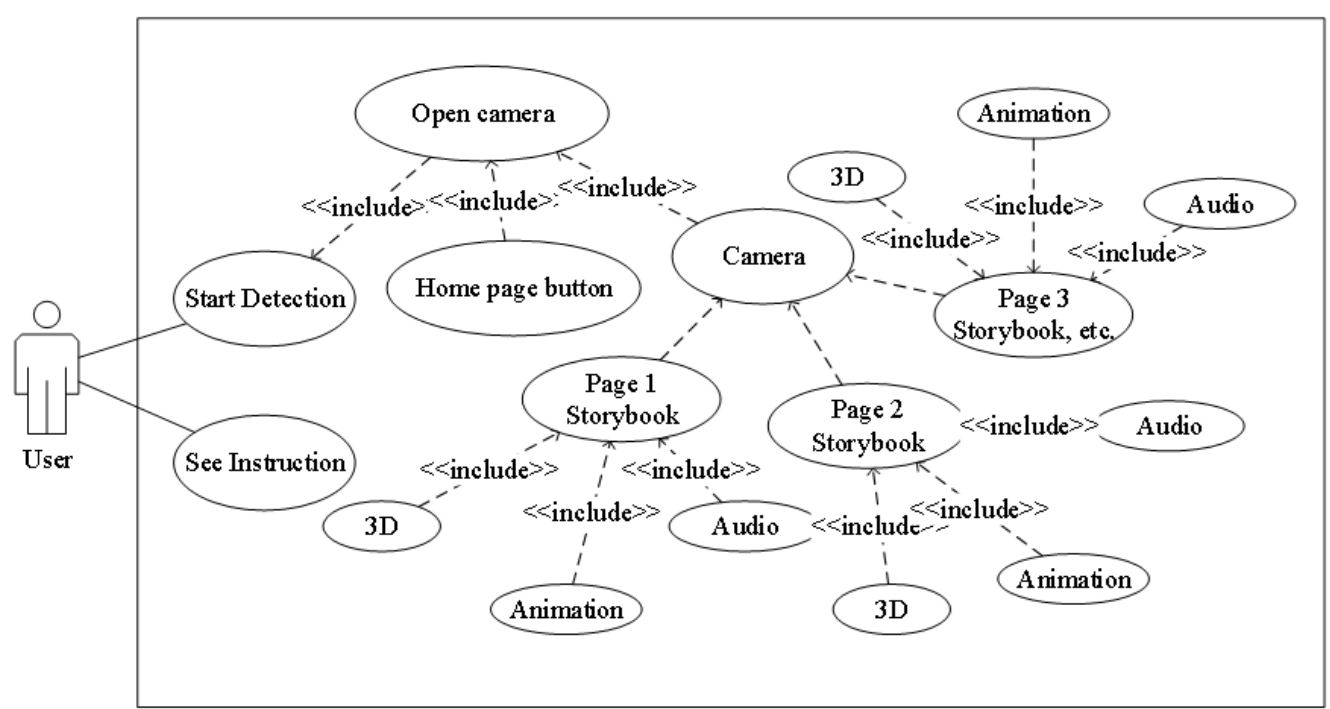

Figure 3. Use case diagram of the Ello Story

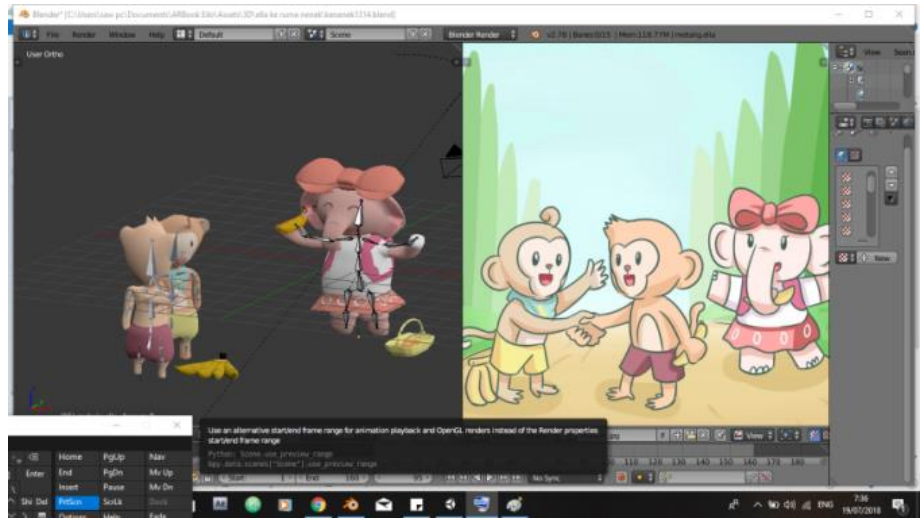

Figure 4. Blender view

\section{Media analysis}

Media analysis aims to select appropriate media delivery strategies. Children who become media users belong to the digital generation. In addition, there is an evolution in the style of learning from verbal, then visual, to virtual, so that the learning media is made to adapt to the children's learning style by using AR technology.

\section{Extent-data analysis}

This analysis aims to identify the learning material. The storybook's material contains financial literacy values such as delayed gratification, saving goals, responsibility, discipline, honesty and money management.

\section{Design Phase}

Unified Modeling Language (UML) is used to simplify the explanation of the system's design contained in the application. UML is one of the modelling languages used in developing the software. UML itself chooses many diagrams, one of which is use case. The use case diagram is a diagram that serves to explain the workflow and functions that run in the application. Figure $\mathbf{3}$ is a use case of the Ello Story diagram.

Besides the use case which was used to design the system, we also needed other software to design interfaces and apply augmented reality to books, applications and also 3D objects. The following are some of the tools used in the application's development process:

1. Blender. Blender is open source 3D software that can be used to create 3D models and animation. A Blender display can be seen in Figure 4. 


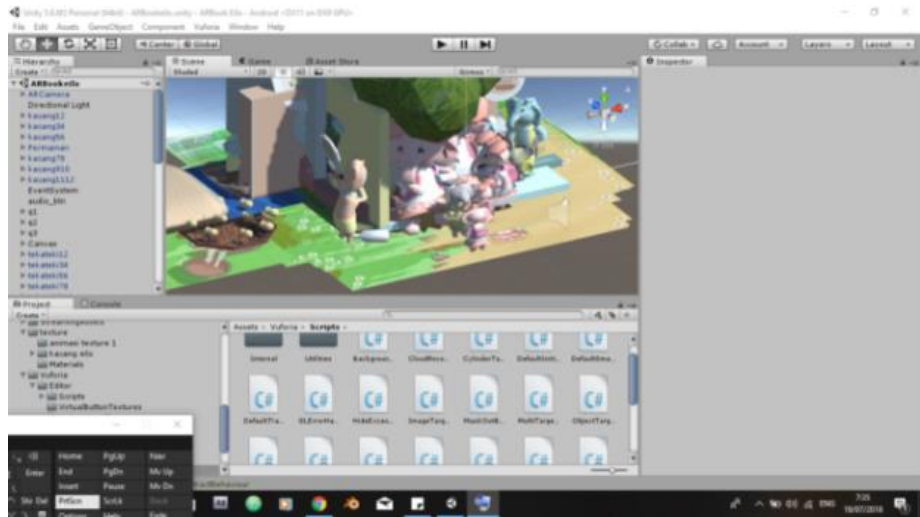

Figure 5. Unity software display

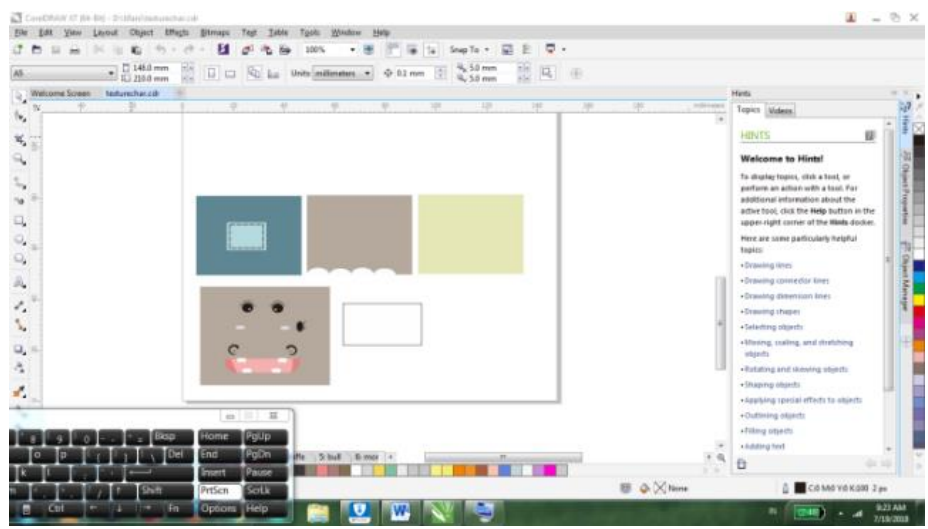

Figure 6. Corel software display
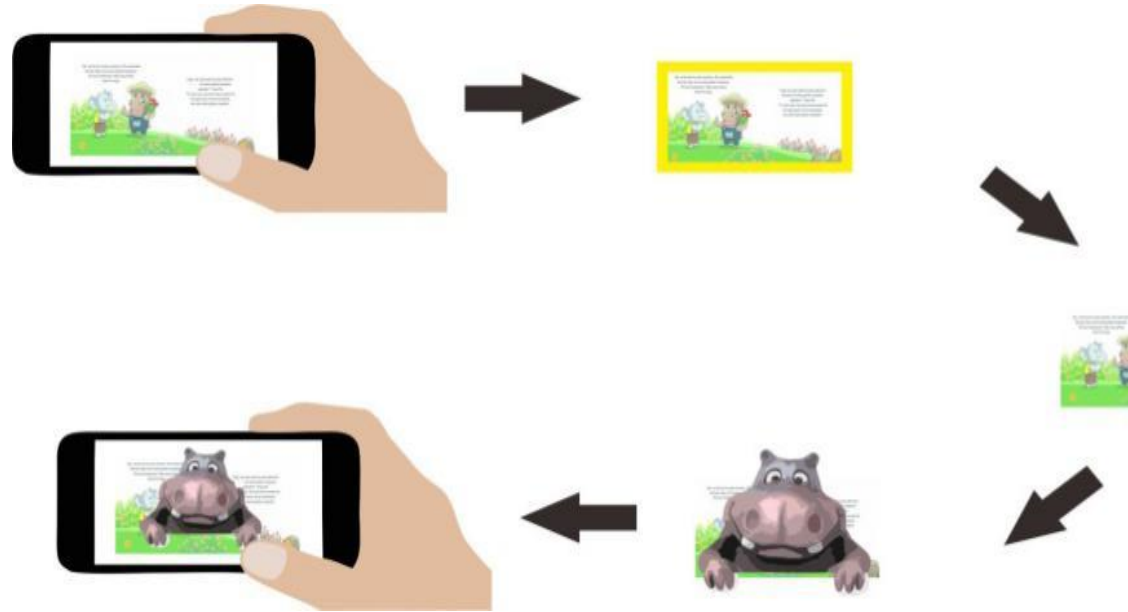

Figure 7. Block diagram of the working principle

2. Unity. Unity is the software used to process 3D images, animation, programme scripts and other things. Unity software's display can be seen in Figure $\mathbf{5}$.

3. Corel Draw x7. Corel Draw is used for designing the menu and texture material for the 3D models. Corel software's display can be seen in Figure 6 .

4. Vuforia. Vuforia is a plug-in or additional feature for Unity that allows us to scan an image, so an object can be placed in it. The block diagram of the working principle, as seen in Figure 7, explains that the scanning process for augmented reality technology can be done by firstly directing the phone towards the marker. Automatically, the application will try to scan the marker and check whether the marker is in the database. Once it is detected, the app will match the marker with its 3D database, after which the 3D animations appear on the Android screen. 


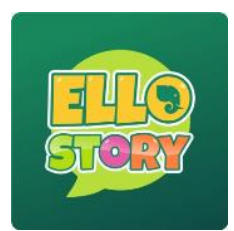

Figure 8. Logo

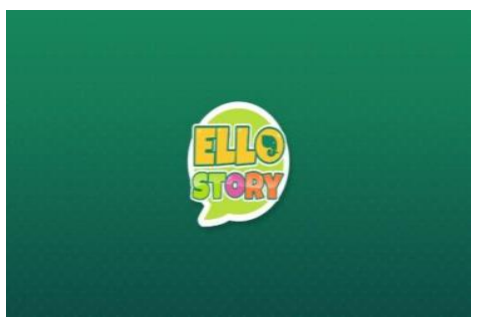

Figure 9. Splash screen

\section{Development Phase}

In the early stages of development, several tools were used, such as Corel Draw and 3D Blender. In addition, the application's development also used the Vuforia software development kit (SDK) and the Android SDK as the basis for developing Android-based augmented reality applications. The process of creating augmented reality can be briefly described as follows:

1. Creating 3D content and animation with the Blender software, such as 3D objects, animation, and pasting material for the 3D model's textures.

2. The creation of 2D content using Corel Draw X7, for example, the interface for the application's users, the marker's image in the storybook and the texture for 3D objects.

3. After finishing the content, we prepared our framework with Unity by importing the Vuforia plug-in.

4. Next was the database. The first thing to be prepared was the database's marker. Database markers can be prepared through the official Vuforia website, where all the required markers can be uploaded and the marker files can be converted into Unity-readable files. Once downloaded, the database can be imported into the Unity software.

5. Next is to position the markers with the 3D objects, as required.

6. All the programs can be built by using the Android SDK inside Unity, and then they can be made into an Android Application Package File (APK).

After the application has been developed, APK can be installed directly on the KitKat android device or above version of android. The following were the results of the application's performance after the development phase had been completed.

1. Ello Story logo. A logo is a symbol or icon used to describe the entire contents of the app being developed. The logo that the Ello Story app uses can be seen in Figure 8.

2. Splash screen page. The splash screen page is a marker that the initial instructional media app opens. The splash screen page's display can be seen in Figure $\mathbf{9}$.

3. Main menu page. The main menu page is the page that opens shortly after the splash screen appears. The main menu page has the following buttons: start button, about button, instruction button, and quit button. The main menu page can be seen in Figure 10. 


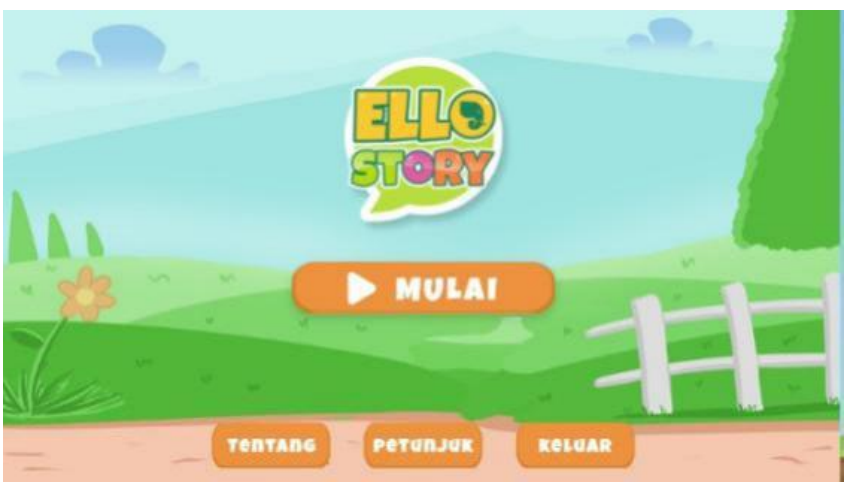

Figure 10. Main menu page

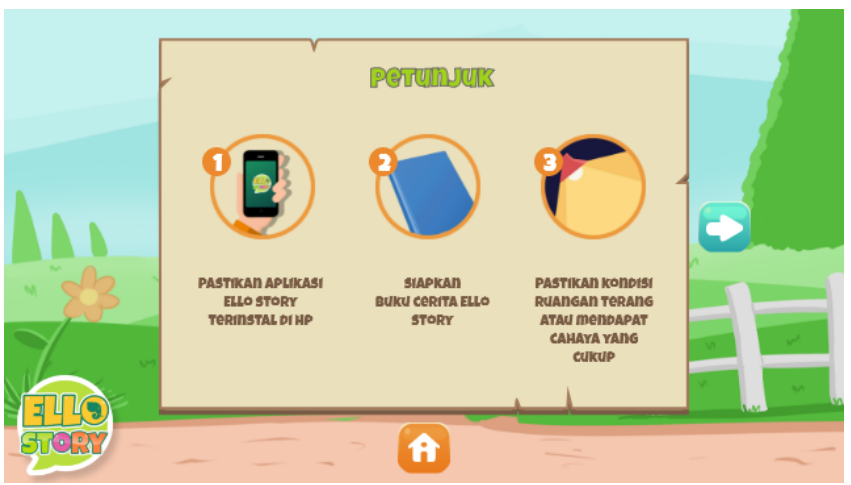

Figure 11. Instruction page

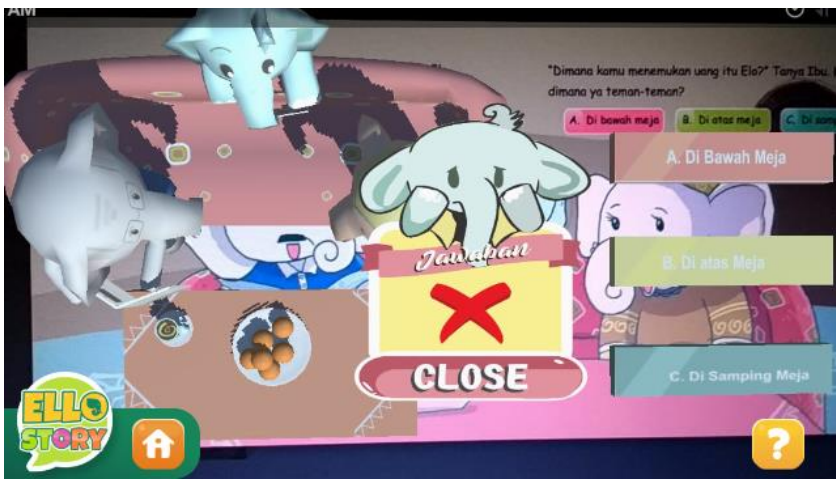

Figure 12. Start page

4. Instruction page. The instruction page will appear after the instruction button on the main page is clicked and will display the app's usage settings in detail. The instruction page is seen in Figure 11.

5. Start page. The start page is the page that will appear after the start button on the main page is clicked and displays the camera view where the marker is scanned and thus the content that will appear is 3D animation with some game interaction content. A view of the start page is shown in Figure $\mathbf{1 2 .}$

\section{Implementation}

\section{Product trial}

The product's trial is the testing phase for the learning media. The trial aims to ensure that the developed learning media is suitable to be used by the proposed users (children). The criteria for assessing learning media using the Learning Object Review Instrument (LORI) developed by Leacock and Nesbit (2007) are: 1) content quality, 2) alignment of learning objectives, 3) feedback and adaptation, 4) motivation, 5) presentation design, 6) interaction usability, 7) accessibility, 8) reusability, and 9) standards compliance. The 
Table 2. LORI theory implemented in the Ello Story

\begin{tabular}{lll}
\hline No Items & Description \\
\hline 1 & Content's quality & It relates to balancing the ideas and the accuracy of the levels \\
2 & Learning goals' alignment & Focus on learning goals and users' characteristics \\
3 & Motivation & Ability to motivate users \\
4 & Presentation's design & Use of features like audio, visuals, and animation to improve the learning process \\
5 & Interaction's usability & Regarding ease of navigation, including an easy user interface \& quality help features \\
\hline
\end{tabular}

Table 3. Results of the material and the media assessment

\begin{tabular}{|c|c|c|c|c|c|c|c|}
\hline \multicolumn{8}{|c|}{ PANEL A. Material assessment } \\
\hline & \multicolumn{4}{|c|}{ Before revision } & \multicolumn{3}{|c|}{ After revision } \\
\hline & $\begin{array}{l}\text { Content's } \\
\text { quality }\end{array}$ & $\begin{array}{r}\text { Leanin } \\
\text { alig }\end{array}$ & $\begin{array}{l}\text { \& goals' } \\
\text { oment }\end{array}$ & Motivation & $\begin{array}{l}\text { Content's } \\
\text { quality }\end{array}$ & $\begin{array}{c}\text { Leaning \& goals' } \\
\text { alignment }\end{array}$ & Motivation \\
\hline Material expert 1 & 56 & & 57 & 58 & 68 & 60 & 65 \\
\hline Material expert 2 & 54 & & 55 & 60 & 69 & 68 & 65 \\
\hline Material expert 3 & 60 & & 62 & 63 & 75 & 76 & 66 \\
\hline \multicolumn{8}{|c|}{ PANEL B. Media assessment } \\
\hline & \multicolumn{4}{|c|}{ Before revision } & \multicolumn{3}{|c|}{ After revision } \\
\hline & \multicolumn{2}{|c|}{ Presentation's design } & \multicolumn{2}{|c|}{ Interaction's usability } & Presentation's design & Interact & Interaction's usability \\
\hline Media expert 1 & \multicolumn{2}{|l|}{69} & \multicolumn{2}{|r|}{70} & \multicolumn{2}{|c|}{75} & 77 \\
\hline Media expert 2 & \multicolumn{2}{|l|}{72} & \multicolumn{2}{|r|}{73} & \multicolumn{2}{|c|}{76} & 78 \\
\hline
\end{tabular}

Total score conversion. Highly feasible: $92>x \geq 74.75$; Feasible: $74.75>x \geq 57.5$; Fairly feasible: $57.5>x \geq 40.25$; Not feasible: $40.25>x \geq 23$

Table 4. Experts' suggestions

\begin{tabular}{lll}
\hline \multicolumn{1}{c}{ Validator } & \multicolumn{1}{c}{ Suggestions from the material experts } \\
\hline PANEL A & Material expert 1 & $\begin{array}{l}\text { Reduction of sentences in the story and increase the number of images because the } \\
\text { target is children of an early age }\end{array}$ \\
& Material expert 2 & There needs to be a conclusion or a digest at the end of the story \\
Material expert 3 & Grammar correction \\
\hline PANEL B & Media expert 1 & $\begin{array}{l}\text { Animation needs to be added to help the children's understanding } \\
\text { Interaction activities need to be added to improve the children's activity } \\
\text { Add background sounds to make it more interesting } \\
\text { Interaction activities need to be added }\end{array}$ \\
\hline
\end{tabular}

application's development, in this study, took into account the theory of LORI. However, in this application, only five of the criteria are implemented (Table 2).

An assessment of the content's quality, the learning goals' alignment and motivation was performed by the three material experts, while the design's presentation and interaction usability assessment was carried out by the two media experts. Table 3 shows the results of the material and the media assessment.

\section{Validation of expert material}

The material experts included a lecturer in early childhood education, an economics lecturer, and a kindergarten teacher. The material's validation aimed to determine the feasibility of the learning material, in terms of the content's quality, learning goals' alignment and motivation. The learning material needs to be validated to ensure whether the content is able to be used to improve children's cognitive skills in financial literacy by activating executive functions. Suggestions and comments from the material experts were used to revise the content. The test results from before and after the improvements are presented in Table $\mathbf{3}$ Panel A, whereas the suggestions for improvements are in Table 4. Based on the results of the material experts' evaluations, there was an improvement, from fairly feasible to feasible, in the content's quality, learning goals' alignment, and motivational aspects, after the revision. 
Table 5. Students' assessments

\begin{tabular}{lccc}
\hline & Mean & Standard deviation & Evaluation \\
\hline Story's attractiveness & 54.1 & 1.19 & Good \\
3D figures & 56.2 & 1.13 & Very good \\
Activity & 56.3 & 1.15 & Very good \\
\hline
\end{tabular}

Table 6. t-test results

\begin{tabular}{|c|c|c|c|c|c|c|c|}
\hline \multirow{2}{*}{ Variable } & \multicolumn{2}{|c|}{ Pre- test } & \multicolumn{2}{|c|}{ Post-test } & \multirow{2}{*}{$\begin{array}{c}\text { Mean } \\
\text { difference }\end{array}$} & \multirow{2}{*}{$\mathrm{p}$-value } & \multirow{2}{*}{ Effect size } \\
\hline & Mean & SD & Mean & SD & & & \\
\hline Delayed gratification & 13.20 & 1.09 & 13.80 & 0.83 & 0.60 & $0.06 *$ & 0.62 \\
\hline Saving goals & 2.60 & 0.89 & 3.20 & 1.09 & 0.60 & $0.06 *$ & 0.60 \\
\hline Honesty & 2.80 & 0.84 & 3.40 & 0.89 & 0.60 & $0.03 * *$ & 0.69 \\
\hline Responsibility & 3.60 & 0.54 & 4.00 & 0.70 & 0.40 & $0.05^{*}$ & 0.64 \\
\hline Discipline & 3.10 & 0.83 & 3.60 & 0.54 & 0.50 & $0.02 * *$ & 0.71 \\
\hline Money management & 3.40 & 1.14 & 4.20 & 0.44 & 0.80 & $0.00 * * *$ & 0.92 \\
\hline
\end{tabular}

Note. ${ }^{* *} p<0.01 ;{ }^{* *} p<0.05 ;{ }^{*} p<0.1 ;$ SD: Standard deviation

\section{Validation by media experts}

The media's validation consisted of two aspects: the presentation's design and interaction's usability. This validation was conducted by a lecturer from the Faculty of Information and Technology and a lecturer from the Faculty of Education Science. Suggestions and comments from these experts were used for the media's improvement. The media's test results from before and after the improvements are shown in panel B of Table 3, while the suggestions for improvements are in Table 4. The media experts stated that from the presentation's design and interaction's usability aspects, the learning media was highly feasible to use.

\section{Product revision}

Based on the suggestions from the material and media experts, the improvements to the augmented reality financial literacy storybook included adding three-dimensional objects to some of the material, adding background sounds and increasing the interaction activity using augmented reality.

\section{Evaluation}

The final phase of this development process was its evaluation. At this stage of the users' experience, students were asked to provide an evaluation related to the aspects of the story's content, its 3D images and the activity in the storybook. The results of the students' evaluations are presented in Table $\mathbf{5}$.

The students considered that the attractiveness of the story's content was good, the 3D images were very good, and the activity in the storybook was also very good. The next step was testing the effectiveness of the media to increase the students' understanding of financial literacy. Paired sample t-test was used to test the effectiveness of the media with a different test of financial literacy understanding before and after learning. Assumptions paired sample test is a normally distributed variable. The Kolmogorov-Smirnov test with results $>0.10$ which is considered normally distributed. The results are presented in Table 6 . The results of the t-test (Table 6) show that there was a marginally significant increase in the delay of gratification ability as measured by the marshmallow test. Before AR-based financial education, the average ability to delay gratification (not tempted by marshmallow) was 13:20 minutes; after AR-based financial education it increased to 13.80 . Likewise, in regard to students' understanding of the purpose of saving and responsibility, there was also a marginally significant increase. Meanwhile, knowledge of honesty, discipline and money management also increased significantly. 


\section{DISCUSSION}

The digital generation was born in a culture where technology is part of the environment, besides which technological advances have also changed students' learning preferences from verbal, visual to virtual. Therefore, it is necessary to integrate technological advances in education. A significant body of research has found empirical evidence of the benefits of using AR technology in schools and colleges (Chen et al., 2017; Sari et al., 2022) but in early childhood it is still scarce. There is still a debate about whether or not the use of AR technology in early childhood curricula is appropriate. Early childhood teachers need to ensure that the technology used in early childhood curricula does more than just follow the trend. The educational settings must lead the learning, not the pursuit of technology that has been used by children in their home. This study contributes to this field by examining the effectiveness of using AR technology in early childhood for financial literacy learning. The present study finding supports the TIME that the interactive characteristic of AR-based media has an impact on their cognition, attitudes and behaviour (Sundar et al., 2012). The use of an AR-based financial literacy storybook can significantly improve knowledge of honesty, discipline and money management.

However, the ability to delay gratification, understand the purpose of saving and responsibility only increased marginally. This finding supports Chen et al. (2019) that the effectiveness of AR use in kindergarten settings is still only slightly supported. The possible reasons are the challenges of using AR in early childhood settings, for example technical difficulties regarding the placement of the phone to scan barcodes that can pop-up 3D images as well as room lighting (Kotzageorgiou et al., 2018). This technical difficulty will trigger cognitive overload which has a negative impact on learning outcomes (Huang et al., 2020). So, it is necessary to emphasize the role of teachers, who have technological literacy, to support the inclusion of AR technology in early childhood education.

\section{CONCLUSIONS AND RECOMMENDATIONS}

The cultivation of financial literacy through augmented reality-based story media is an attempt to activate the rapidly growing executive functions in children aged 3 to 5 years old. Finance is an abstract concept for children, so appropriate media is needed to teach it to children. Augmented technology allows students to visualise complex relationships and abstract concepts. This study aimed to develop and test the effectiveness of an AR-based financial literacy storybook.

Based on the result, a financial literacy storybook, in the context of augmented reality, was successfully designed and developed using the ADDIE model. This media produced a positive response among the users. By using a pre and post-test design, testing the effectiveness of the AR-based storybook indicated an increase in understanding of financial literacy. This AR-based financial literacy storybook significantly improves the understanding of certain aspects of financial literacy in early childhood: knowledge of honesty, discipline and money management. However, the ability to delay gratification, understand the purpose of saving and responsibility only increased marginally.

These findings prove that there is significant potential in using augmented realty as a learning media for early-age children. The implementation of financial literacy education through appropriate learning media for early-age children is expected to support government programmes to increase the level of financial literacy. Apart from its various contributions, this research has limitations. This study was a short-term one; further research can develop learning media for teaching financial literacy as a long-term implementation, so that the impact can be seen in student's behaviour and not just be limited to knowledge. Also, further research will need to consider whether the use of AR causes cognitive overload in early-age students.

Author contributions: All authors were involved in concept, design, collection of data, interpretation, writing, and critically revising the article. All authors approve final version of the article.

Funding: The study is financially support be Indonesia Endowment Fund for Education (LPDP) under grant no PRJ-44/LPDP/2020.

Declaration of interest: Authors declare no competing interest.

Data availability: Data generated or analysed during this study are available from the authors on request. 


\section{REFERENCES}

Beisly, A., Kwan, K.-A., \& Shinyoung, J. (2019). Executive function and learning behaviors: Associations with academic skills among preschoolers. Early Child Development and Care, 190(15), 2469-2483. https://doi.org/10.1080/03004430.2019.1585347

Bistaman, I. N. M., Idrus, S. Z. S., \& Abd Rashid, S. (2018). The use of augmented reality technology for primary school education in Perlis, Malaysia. Journal of Physics: Conference Series, 1019, 012064.

Bower, M., Howe, C., McCredie, N., Robinson, A., \& Grover, D. (2014). Augmented reality in education-cases, places, and potentials. Educational Media International, 51(1), 1-15. https://doi.org/10.1080/ 09523987.2014.889400

Cascales, A., Laguna, I., Pérez-López, D. C., Perona Ruiz, P. D., \& Contero, M. (2013). An experience on natural sciences augmented reality contents for preschoolers. Lecture Notes in Computer Science, 8022, 103112. https://doi.org/10.1007/978-3-642-39420-1_12

Chen, C.-H., Lee, I.-J., \& Lin, L.-Y. (2016). Augmented reality-based video-modeling storybook of nonverbal facial cues for children with autism spectrum disorder to improve their perceptions and judgments of facial expressions and emotions. Computers in Human Behavior, 55(Part A), 477-485. https://doi.org/10.1016/j.chb.2015.09.033

Chen, Y., Wang, Q., Chen, H., Song, X., Tang, H., \& Tian, M. (2019). An overview of augmented reality technology. Journal of Physics: Conference Series, 1237(2), 022082. https://doi.org/10.1088/1742$6596 / 1237 / 2 / 022082$

Chen, P., Liu, X., Cheng, W., \& Huang, R. (2017). A review of using augmented reality in education from 2011 to 2016. In E. Popescu, Kinshuk, M. K. Khribi, M. Jemni, N.-S. Chen, \& D. G. Sampson (Eds.), Innovations in Smart Learning. Lecture Notes in Educational Technology. Springer, Singapore. https://doi.org/10.1007/978-981-10-2419-1_2

Consolvo, S., Mcdonald, D. W., \& Landay, J. A. (2009). Theory-driven design strategies for technologies that support behavior change in everyday life. In Proceedings of the 27th International Conference on Human Factors in Computing Systems (pp. 405-414), Boston, MA, USA. https://doi.org/10.1145/ 1518701.1518766

Devincenzi, S., Kwecko, V., de Toledo, F. P., Mota, F. P., Casarin, J., \& Silva da Costa Botelho, S. (2017). Persuasive technology: Applications in education. In 2017 IEEE Frontiers in Education Conference (pp. 1-7). https://doi.org/10.1109/FIE.2017.8190439

Diamond, A. (2013). Executive functions. Annual Review of Psychology, 64, 135-68. https://doi.org/10.1146/ annurev-psych-113011-143750

Dick, W., Carey, L., \& Carey, J. (2014). The systematic design of instruction. Pearson.

Drever, A. I., Odders-White, E., Kalish, C. W., Else-Quest, N. M., Hoagland, E. M., \& Nelms, E. N. (2015). Foundations of financial well-being: Insights into the role of executive function, financial socialization, and experience-based learning in childhood and youth. Journal of Consumer Affairs, 49(1), 13-38. https://doi.org/10.1111/joca.12068

Fortin, D. R., \& Dholakia, R. R. (2005). Interactivity and vividness effects on social presence and involvement with a web-based advertisement. Journal of Business Research, 58(3), 387-396. https://doi.org/ 10.1016/S0148-2963(03)00106-1

Garzón, J., Pavón, J., \& Baldiris, S. (2019). Systematic review and meta-analysis of augmented reality in educational settings. Virtual Reality, 23(4), 447-459. https://doi.org/10.1007/s10055-019-00379-9 
George, D., \& Mallery, P. (2003). SPSS for Windows step by step: A simple guide and reference. 11.0 update. Allyn \& Bacon.

Gun, E. T., \& Atasoy, B. (2017). The effects of augmented reality on elementary school students' spatial ability and academic achievement. Education and Science, 42(191), 31-51.

Han, J., Jo, M., Hyun, E., \& So, H.-J. (2015). Examining young children's perception toward augmented realityinfused dramatic play. Educational Technology Research and Development, 63(3), 455-474. https://doi.org/10.1007/s11423-015-9374-9

Harvey, H. A., \& Miller, G. E. (2017). Executive function skills, early mathematics, and vocabulary in head start preschool children. Early Education and Development, 28(3), 290-307. https://doi.org/10.1080/ 10409289.2016.1218728

Hayashi, T. (1990). The Japanese experience in technology: From transfer to self-reliance. United Nations University Press.

Holden, K., Kalish, C., Scheinholtz, L., Dietrich, D., \& Novak, B. (2009). Financial literacy programs targeted on pre-school children: Development and evaluation. La Follette School of Public Affairs. https://lafollette.wisc.edu/images/publications/workingpapers/holden2009-009.pdf

Hsu, W. Y., Lane, H. Y., \& Lin, C. H. (2018). Medications used for cognitive enhancement in patients with Schizophrenia, Bipolar disorder, Alzheimer's disease, and Parkinson's disease. Frontiers in Psychiatry, 9, 91. https://doi.org/10.3389/fpsyt.2018.00091

Huang, Y., Li, H., \& Fong, R. (2016). Using augmented reality in early art education: A case study in Hong Kong Kindergarten. Early Child Development and Care, 186(6), 879-894. https://doi.org/10.1080/03004430. 2015.1067888

Huang, R., Tlili, A., Chang, T. W., (2020). Disrupted classes, undisrupted learning during COVID-19 outbreak in China: Application of open educational practices and resources. Smart Learning Environments, 7, 19. https://doi.org/10.1186/s40561-020-00125-8

Javornik, A. (2016). 'It's an illusion, but it looks real!' Consumer affective, cognitive and behavioural responses to augmented reality applications. Journal of Marketing Management, 32(9-10), 987-1011. https://doi.org/10.1080/0267257X.2016.1174726

Karlsson, I., Bernedixen, J., Ng, A. H. C., \& Pehrsson, L. (2017). Combining augmented reality and simulationbased optimization for decision support in manufacturing. In Proceedings of the 2017 Winter Simulation Conference (pp. 3988-3999). https://doi.org/10.1109/WSC.2017.8248108

Klopfer, E., \& Squire, K. (2008). Environmental detectives-the development of an augmented reality platform for environmental simulations. Education Technology Research and Development, 56, 203-228. https://doi.org/10.1007/s11423-007-9037-6

Kotzageorgiou, M., Kellidou, P. M., Voulgari, I., \& Nteropoulou, E. (2018). Augmented reality and the symbolic play of pre-school children with autism. In K. Ntalianis, A. Andreatos, \& C. Sgouropoulou (Eds.), Proceedings of the 17th European Conference on e-Learning (pp. 273-280). University of West Attica.

Leacock, T. L., \& Nesbit, J. C. (2007). A framework for evaluating the quality of multimedia learning resources. Educational Technology \& Society, 10(2), 44-59.

Lynch Jr., J. G., Netemeyer, R. G., Spiller, S. A., \& Zammit, A. (2010). A generalizable scale of propensity to plan: The long and the short of planning for time and for money. Journal of Consumer Research, 37(1), 108-128. https://doi.org/10.1086/649907 
Martin, S., Diaz, G., Sancristobal, E., Gil, R., Castro, M., \& Peire, J. (2011). New technology trends in education: Seven years of forecasts and convergence. Computers \& Education, 57(3), 1893-1906. https://doi.org/ 10.1016/j.compedu.2011.04.003

McClelland, M. M., Acock, A. C., Piccinin, A., Rhea, S. A., \& Stallings, M. C. (2013). Relations between preschool attention span-persistence and age 25 educational outcomes. Early Childhood Research Quarterly, 28(2), 314-324. https://doi.org/10.1016/j.ecresq.2012.07.008

McDermott, P. A., Rikoon, S. H., \& Fantuzzo, J. W. (2014). Tracing children's approaches to learning through head start, kindergarten, and first grade: Different pathways to different outcomes. Journal of Educational Psychology, 106(1), 200-213. https://doi.org/10.1037/a0033547

Meier, S., \& Sprenger, C. D. (2012). Time discounting predicts creditworthiness. Psychological Science, 23(1), 56-58. https://doi.org/10.1177/0956797611425931

Mitnik, R., Recabarren, M., Nussbaum, M., \& Soto, A. (2009). Collaborative robotic instruction: A graph teaching experience. Computers \& Education, 53(2), 330-342. https://doi.org/10.1016/j.compedu. 2009.02.010

Miyake, A., Friedman, N. P., Emerson, M. J., Witzki, A. H., Howerter, A., \& Wager, T. D. (2000). The unity and diversity of executive functions and their contributions to complex 'frontal lobe' tasks: A latent variable analysis. Cognitive Psychology, 41(1), 49-100. https://doi.org/10.1006/cogp.1999.0734

Moffitt, T. E., Arseneault, L., Belsky, D., Dickson, N., Hancox, R. J., Harrington, H., Houts, R., Poulton, R., Roberts, B. W., Ross, S., Sears, M. R., Thomson, W. M., \& Caspi, A. (2011). A gradient of childhood selfcontrol predicts health, wealth, and public safety. Proceedings of the National Academy of Sciences, 108(7), 2693-2698. https://doi.org/10.1073/pnas.1010076108

OECD. (2018). PISA 2018 financial literacy framework. OECD ilibrary. https://www.oecdilibrary.org/education/pisa-2018-assessment-and-analytical-framework_a1fad77c-en

OJK. (2019). Survei nasional literasi dan inklusi keuangan 2019 [2019 National financial literacy and inclusion survey]. Otoritas Jasa Keuangan [Financial Fervices Authority]. https://www.ojk.go.id/id/berita-dankegiatan/publikasi/Pages/Survei-Nasional-Literasi-dan-Inklusi-Keuangan-2019.aspx

Purpura, D. J., Schmitt, S. A., \& Ganley, C. M. (2017). Foundations of mathematics and literacy: The role of executive functioning components. Journal of Experimental Child Psychology, 153, 15-34. https://doi.org/10.1016/j.jecp.2016.08.010

Rasalingam, R.-R., Muniandy, B., \& Rass, R. R. (2014). Exploring the application of augmented reality technology in early childhood classroom in Malaysia. IOSR Journal of Research \& Method in Education, 4(5), 33-40. https://doi.org/10.9790/7388-04543340

Rohaya, D., Rambli, A., Matcha, W., Sulaiman, S., \& Nayan, M. Y. (2012). Design and development of an interactive augmented reality edutainment storybook for preschool. IERI Procedia, 2, 802-807. https://doi.org/10.1016/j.ieri.2012.06.174

Safar, A. H., Al-Jafar, A. A., \& Al-Yousefi, Z. H. (2016). The effectiveness of using augmented reality apps in teaching the English alphabet to kindergarten children: A case study in the State of Kuwait. EURASIA Journal of Mathematics, Science and Technology Education, 13(1), 417-440. https://doi.org/10.12973/ eurasia.2017.00624a

Sari, R. C., Fatimah, P. L. R., Ilyana, S., \& Hermawan, H. D. (2022). Augmented reality (AR)-based sharia financial literacy system (AR-SFLS): A new approach to virtual sharia financial socialization for young learners. International Journal of Islamic and Middle Eastern Finance and Management, 15(1), 48-65. https://doi.org/10.1108/IMEFM-11-2019-0484 
Squire, K. D., \& Jan, M. (2007). Mad city mystery: Developing scientific argumentation skills with a placebased augmented reality game on handheld computers. Journal of Science Education and Technology, 16, 5-29. https://doi.org/10.1007/s10956-006-9037-z

Squire, K. D., \& Klopfer, E. (2007). Augmented reality simulations on handheld computers. The Journal of the Learning Science, 16(3), 371-413. https://doi.org/10.1080/10508400701413435

Sundar, S. S., Bellur, S., \& Jia, H. (2012). Motivational technologies: A theoretical framework for designing preventive health applications. In: M. Bang, \& E. L. Ragnemalm (Eds.), Persuasive technology. Design for health and safety (pp. 112-122). Springer. https://doi.org/10.1007/978-3-642-31037-9_10

Sundar, S. S., Jia, H., Waddell, T. F., \& Huang, Y. (2015). Toward a theory of interactive media effects (TIME): Four models for explaining how interface. In S. S. Sundar (Ed.), The handbook of the psychology of communication technology (pp. 47-86). John Wiley \& Sons, Inc. https://doi.org/10.1002/ 9781118426456.ch3

Whitebread, D., \& Bingham, S. (2013). Habit formation and learning in young children. Money Advice Service.

Zimmerman, J., Pathak, P., \& Holmes, J. (2011). Accelerating financial capability among youth: Nudging new thinking. New America. https://www.newamerica.org/asset-building/policy-papers/acceleratingfinancial-capability-among-youth-nudging-new-thinking/

Correspondence: Ratna Candra Sari, Department of Accounting Education, Faculty of Economics, Universitas Negeri Yogyakarta, Indonesia. E-mail: Ratna_candrasari@uny.ac.id 
APPENDIX A

Demographics of the Participants

\begin{tabular}{lccc}
\hline & Min & Max & Mean \\
\hline Age & 4 & 6 & 5,2 \\
Parents' education level & Senior high school & Bachelor degree & Doctoral program \\
Percentage (\%) & $6 \%$ & $82 \%$ & $12 \%$ \\
\hline
\end{tabular}

